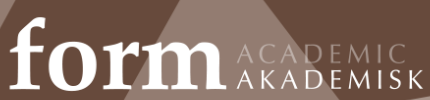

\title{
triv
}

Anita Neuberg

Assistant Professor

Oslo Metropolitan University, Norway

anitaneuberg@gmail.com

Vol I4, No 4 (202I)

\section{Social innovation for modified consumption by means of the school subject Art and crafts $^{1}$}

\begin{abstract}
In this paper I will take a look at how one can facilitate the change in consumption through social innovation, based on the subject of art and design in Norwegian general education. This paper will give a presentation of books, featured relevant articles and formal documents put into context to identify different causal mechanisms around our consumption. The discussion will be anchored around the resources and condition that must be provided to achieve and identify opportunities for action under the subject of Art and crafts, a subject in Norwegian general education with designing at the core of the subject, ages 6-16. The question that this paper points toward is: How can we, based on the subject of Art and crafts in primary schools, facilitate the change in consumption through social innovation?
\end{abstract}

Keywords:

Consumption, production, biology, pedagogy

\section{INTRODUCTION}

The world's population is expected to flatten out around 10 billion people, and it will, according to Dag $\mathrm{O}$. Hessen, require two planets to provide all an average Norwegian consumption and emissions. It is obvious that we cannot continue with such a consumption. The alternative to saving the planet must be either tomorrow's technology, or that we all take a little less space when it comes to consumption and emissions of greenhouse gases $(2010$, p. 224,253). In this paper I will take a closer look on how we might take a bit less space, therefore I have ruled out technology optimism, although it is an interesting topic 
in terms of consumption. To further refine the task, I will introduce some research around the Norwegian clothing consumption. According to Statistics Norway (SSB), the volume of our clothing consumption increased despite the fact that our clothing spending has decreased $(1999,2013,2014)$. In Pål Strands' Article We buy more of the most, it appears that we have had a quadruple in the consumption of clothes and shoes since the 1980's, and he is putting imports from low-cost countries in Asia to the basis of this development (2014). According to Carbon Trust, production and laundry of clothes account for $3 \%$ of global emissions, measured in $\mathrm{CO} 2$ equivalents (2011). This excludes chemicals, working conditions, energy, and resource usage. Carbon Trust also points out that the longevity and quality of clothes is a major factor for the Environment (Carbon Trust, 2011).

This paper is about people's relationship with their own consumption, what causal mechanisms that affect our consumption, and how we can relate to future challenges. As Matthias Kaiser and Ingrid Louise Ugelvik (2000) writes, we perceive things from our personal assumptions such as life history, experiences, values, attitudes and knowledge. Therefore, it will be natural to me, as an art and design teacher in the subject Art and crafts, a subject in Norwegian general education with Designing at the core of the subject, ages 6-16, to implement the interdisciplinary aspect. I would therefore give an insight into why, and how we can use this in a teaching context. Gunnar Vitters $\varnothing$ and Pål Strandbakken (2016, p. 23) points out that knowledge about the environment and climate challenges requires an interdisciplinary approach, which I will try to do here. I will not derive any theories, but present a hypothesis on how we, through the arts and craft, can facilitate social innovation for modified consumption.

How can we, based on the subject of Art and crafts in primary schools, facilitate the change in consumption through social innovation?

\section{APPROACH METHOD}

This paper is based on what Runa Patel and Bo Davidson refer to as theoretical anchoring (1999, p. 11). The method I have put to use is a qualitative literature study, in which I have systematic review of selected literature around the issue. One might say that I have worked out from the hermeneutical spiral (Patel \& Davidson, 1999, p. 26), where I read and interpret texts, then put them in context to each other, to form an understanding, and we get a new text production, a new interpretation and a new understanding. My empiricism is therefore based on various articles, formal documents and books. Which I attempt to put in context with each other in an effort to identify possible causal mechanisms influencing our consumption and reflecting on what actions that can contribute to change our action patterns. The selection of literature is mainly the book of Dag O. Hessen, professor in biology, Nature-What are we going to do with it (2010), a book on the topic of pedagogy and philosophy, as The anxiety of the upbringing of associate professor of education and environmental science Per Bjørn Foros and professor of philosophy at the University of Oslo Arne Johan Vetlesen (2015), as well as articles on relevant research related to this topic, and formal documents. This is to achieve the interdisciplinary approach I want.

\section{CAUSAL MECHANISMS AND OUR CONSUMPTION Cultural and social causes of consumption}

In the book The anxiety of the upbringing, Foros and Vetlesen (2015, p. 144) points out, that we cannot solve climate problems without looking at the cultural and societal causes. Children grows up in a globalized culture, in which there is an asymmetrical power relationship between the individual and global society. They write that consumption has become a key to self-realization, and that self-realization works as a requirement from society. The individual's freedom and the right to choose weigh heavy, and with wrong choices, the individual alone is left with the blame. Foros and Vetlesen points out that this social feature is in the way of political solutions, where interventions can be perceived as a limitation of personal freedom (2015, p. 63). Something like Vitters $\varnothing$ and Strandbakken confirms in their article "Consumption and the green shift» (2016, p. 17). Hessen writes that Norwegian politicians avoid pointing at individual responsibility, because they believe it is an impossible political task (2010, 
p. 246,247). This image of the reluctant politicians is being confirmed by Sjur Kasa (2016), which describes political attitudes toward the consumer; as unable to make environmentally friendly choices without economic intensives. At the same time, Hessen draws a picture of people wanting to contribute to a better environment, but that they want a stronger political will $(2010, p .240)$. This creates an error in politician's argument, who arrange to just continue as before.

\section{Evolution, action patterns, consumption and producers}

Why is it important to understand the role of evolution in our actions? Why is it important with an individual focus on consumerism? As I interpret Kaiser and Ugelvik is the individual the most fundamental size in the modern society (2000). According to Hessen (2010), we cannot get away from evolutionary influences on us, but at the same time, modern society requires some rather different characteristics form us, than what was important for survival earlier. We have been hunters and collectors in 99 percent of human history, and these impulses are not easy to change (Hessen, 2010). Hessen points out, among other things that «... We are abundantly equipped with gas pedals, but few brake pedals» (2010, p. 251). We are evolutionary adapted to "Here-and-Now Options" (Hessen, 2010, p. 230), which was beneficial as we lived on the savannah, but that is not as beneficial in a modern society with access to everything we need and desire of goods. As Hessen writes, it is the sum of our individual action patterns which contribute to the state of the globe (2010, p. 222). Foros and Vetlesen stressed that the problem lies in the volume of commodity production (2015, p. 113). As I interpret Hessen, does increased consumes equals increased waste, increased $\mathrm{CO} 2$ emissions and Increased greenhouse gas emissions which threaten our globe.

So why don't we decrease consumption? Could it be that manufacturers are looking to increase our consumption? "It is a market-driven, but unwanted dynamism and business-Darwinism in the society development that makes the current solutions passé before we have grown accustomed to them" (Hessen, 2010, p. 121), with the result that the rate of exchange increases (Hessen, 2010, p. 122). Pål Strandbakken also writes about this theme, with the explanation that when things are cheaper to buy new, than to repair, this affects the consumers choice. It must also be mentioned that according to the article Product life and product quality that reduced consumption? (Strandbakken, 2016), it will always pay off for the consumer, both financially and environmentally to emphasize products with good quality.

As mentioned initially, we are on a consumption that is in disparity to natural resources. Vitters $\varnothing$ and Strandbakken presents various strategies that can reduce the environmental impact in which the reduction in the actual consumption of goods and services in the household, is identified as the most difficult to implement (2016). The question is, do we have this ability to readjust ourselves to a smaller consumption? As I interpret Hessen, there is an absolute potential for it since we humans have an impressive adaptability (2010, p. 248). We humans have the opportunity to change habits and identity, because we, as human beings are in an interaction between identity and society, as Rune Sarromaa Hausstätter and Sanna Sarromaa (2009) write in their article $A$ theoretical contribution to an in-law education. Vitters $\varnothing$ and Strandbakken (2016) expresses that the consumer perspective does not get enough focus in the green shift, and that adaptation of our consumption is critical in terms of environment and climate change. They look at social innovations as a prerequisite. I believe that the school can, and should play an important role here.

\section{Abstraction to production}

Hessen notes that urbanization leads to a form of abstraction to nature, and writes that the bill for consumption of nature is passed on to future generations (2010, p. 178). But I question whether or not the bill is also sent to the production countries, with a much closer time perspective?

I would think that modernization and our consumption habits to have had a form of abstraction in relation to the resources used. Take for example the production of clothes, with all of the different resource used, including the human labor, the local challenges, and the immediate impact of the environment in the vicinity of emissions of toxins. In order to not forget the use of energy and resources throughout the process of manufacturing the actual product itself, its material and raw materials. As 
Ingun Grimstad Klepp and Kirsi Laitala points out in the article Clothes life-LCA on life and death, these items are difficult to measure (2016). Based on Norwegian conditions, Hessen takes up that protection of land and species should have a local anchoring, ideally, and he points out that the conditions for this framework is changing (2010, p. 121). I am thinking that, yes, the framework for the conditions change, and that today we are responsible for the emissions that occur in other countries on behalf of our consumption, and thus also a responsibility for the protection of areas and species in a global perspective. Which Hessen himself points out, the average Norwegian have the same high Co2 emissions in China, as the average Chinese (2010, p. 229). To change this, we must contribute to these good social innovations such as Vitters $\varnothing$ and Strandbakken calls for, previously mentioned in section 3.2.

How about appealing to humanity and empathy? Will we then be able to fight lack of understanding and sympathy for the future generations? Hessen points out that we, as social beings, have empathy that extends beyond ourselves. He is questioning how far this empathy and immersion can be stretched $(2010$, p. 126, 128), both when it comes to species and the future generations. I think it certainly should be able to stretch to reach living people, and that this can cause upgrowing generations to feel and relate with workers in Bangladesh. The Starting point for biophilia is, as I interpret Hessen (2010, p. 147) that we as human beings are more willing to stand up for someone who is closer to us.

Can we, if we based on biophilia as phenomenon, combined with empathy and immersion, be creating a focus on people's working conditions and different environmental impacts that our consumption provides the local environment? Can knowledge and information on production in other countries Influence the individual's ability to act and work against the biological instincts?

As I understand Kaiser and Ugelvik (2000), our ability to judge situations is about our ability to experience them through different perspectives; If one is introduced to different contexts, one also gets new insights, we understand better and can justify our choices better. Foros and Vetlesen points towards Kant's Distance ethics, that a principle cannot only apply to anyone, it must be able to apply to everyone. So that when we are facing a choice, then we have to imagine that everyone else does the exact same thing, and form that, consider whether we can bear the consequences (2015, p.201).

\section{A LOOK AT THE FUTURE}

\section{Future optimism or future determinism?}

The location of man at the top of the hierarchy has long traditions from antiquity to the present day (Chalmer, 2013; 4. Kaiser \& Ugelvik, 2000; Hessen, 2010). There were little changes at most people in ancient times, but after the renaissance the belief that future generations would get better than previous generations arose (Kaiser \& Ugelvik, 2000). Hessen is on to something when he writes that the human cultural project is mainly about cutting the ties to nature (2010, p. 96), but that we must now move from being man against nature, to protect the nature against people (Hessen, 2010, p. 27). This increased focus on the climate crisis is about to take away the belief in the future. This is being replaced with increased concern for the future (Foros \& Vetlesen, 2015). Hessen uses the term "meta- concern" about the concerns for the planet's future, and as I interpret him, it is a concern that is difficult to do something about (2010, p. 214). I believe this can contribute to a powerless and hopelessness among up growing generations, which will contribute to a "give damn attitude".

The question is then how children and adolescents can get outlets for these feelings, and how I as an adult person and teacher, can create hope? According to Foros and Vetlesen (2015), all adult persons are responsible for educating and raising children and adolescents, conveying joy of life and faith for the future without concealing the seriousness and urgency of the situation. What seems daunting and incomprehensible needs to be explained, both how it has become so and how it can be better (p. 103). The way I interpret Foros and Vetlesen, it is important that the children get the tools they need to make good decisions on their own. This can prepare the future generations for the life they will live and the Society they will become a part of. Experience of opinion creates greater hope and vigor (2015, s.208). Hausstätter and Sarromaa mention that pedagogy with an environmental focus is an important element in the environmental challenge (2009). They point out that the pedagogy largely puts man in the center, but that the pedagogy must seek away from this starting point with increased focus on the 
relationship between people and the environment. I think these are important elements for social innovation through the school system.

\section{Tendencies in formal documents}

If we take a look at some formal documents, we might see some tendencies presented in the future school. In the white paper Motivation-Mastery-Possibilities. Lower secondary education (Meld. St. 22 (2010-2011), p. 38) they write that Art and crafts subject is one of the subjects the students are most satisfied with, nevertheless it is not embroidered the importance and usefulness of the subject but is emphasized as a method to use in other subjects. This shows that the subject's specificity is not communicated clearly enough from the field.

According to Knowledge for a Common Future. Strategic plan, the Revised Education Strategy for Sustainable Development, education is going to influence people's mindset and attitudes towards more focus on fair and sustainable development (The Ministry of education, 2012). UNESCO, which is the United Nations Organization for education, science, culture and communication, is conducting measures for increased expertise in the field. They emphasize that all subject disciplines support this goal. (Ministry of education, 2012). But I have to point out that subjects such as mathematics, language subjects, social sciences, science, religion and philosophy were mentioned in the strategy plan, but not the Art and crafts subject, which I find strange.

In Norwegian public inquiry School of the future (NOU 2015:8). They write that the practical aesthetic subjects are carriers of important skills for future workplaces, and for the students' ability to make ethical considerations and good decisions in one's own life, referred to as a life skill and everyday competence (NOU 2015:8, p. 25).

The politicians in Subjects-Depth-Understanding, want it to be made easier for individual subjects to be seen in the context of other subjects that have related topics (Meld. St. 28, 2015-2016, pp. 32,37).

In the General section- values and principals the overall goals for education in Norwegian primary school are presented. This should be the basis for the education in all subjects. Based on the purpose law of the Education Act (Kunnskapsdepartementet, 2017, p. 2). The values of the education are based on human dignity, culture, identity, diversity, critical thinking and ethical awareness, in addition to creativity, commitment, exploration, democracy and participation. Principles of learning and development is all about the development of students' formations, holistic competence, knowledge about learning and presentation of interdisciplinary topics. It is pointed out that the practical work and the theoretical reasoning is important for understanding, reflecting and thinking critically in subjects (Ministry of education, 2017a, p. 11). One of the points in the value base is about respect for nature. That the students will gain knowledge to learn about nature, developing ethical awareness and develop respect for nature. The school shall facilitate for students to develop a willingness to care for the environment, and the will to make changes in our way of life, and thereby take care of all life on Earth. They Should be made aware of how the human way of life affects the nature, the climate and our society (p. 8.)

As we can see here, the politicians are trying to increase the focus on sustainability in the education system. Still, I am afraid that the Art and crafts subject's potential in educating upcoming generations within the topic of environment and climate issues will continue to be under communicated. This made me think that my field of expertise needs a greater understanding of the global environmental issues, so that we can more clearly convey our skills and opportunities to contribute to solving parts of the climate problem.

\section{WHY THE SUBJECT OF ART AND CRAFTS?}


I will try to show how Art and crafts subject are important and useful, as more than a method to support other subjects, and try to communicate some of the subject's specificity that lacked in Motivation-Mastery-Possibilities. Lower secondary education. At the same time, it is important to show the interdisciplinary related topics that Subjects-Depth-Understanding calls for to give the students' knowledge of the environment, the human impact on nature, climate and in a globalized world that General section-values and principals expects the school to facilitate. And that the Art and crafts subject also can influence people's mindset and attitudes towards more focus on fair and sustainable development, even though not mentioned in Knowledge for a Common Future.

Hessen points out that the curve of life happiness in this country flattened out in the late 60's, while our consumption has continued to grow $(2010$, p. 229,254). This has been confirmed by Foros and Vetlesen, who points out that the psychological happiness does not follow materialism, but that it rather appears as an obstacle to perceived happiness $(2015$, p. 21). The western population is increasingly seeking freedom from the materialism (Hessen, 2010, p. 255). At the same time our clothing consumption increases. This shows, as Christine Løkvik and Janne Beate Reitan (2017) points out that sustainability and fashion are important for the general public as critical consumers. According to Monica Shlanbusch Orheim and Liv Merete Nielsen (2017) the conscious consumer needs to be trained, and points out that one of the challenges is "...how to bring these ideas into educational practice in a way that connects to students' choices in their everyday lives." (2017, p.2). Strandbakken (2016) notes that clothing creates identity, and as we have mentioned previously, consumption is a key to self-realization. But are there other, more sustainable alternatives to self- realization through clothes?

"When is life good to Live? » Hessen asks (2010, p. 259) as he continues to ask questions around what gives us people a sense of well-being and what makes life feel meaningful. He explains about the feeling of happiness that occurs in ski tours associated with toil and sees it in the light of both endorphins, moral reward and not to mention the feeling of being alive (2010, p. 79). Hessen writes that nature experiences provide and creates deep emotions and feeling that life is good to live, that the origin of the feeling is not the most important thing, but that the quality of life is the essence (2010, p. 100). If we focus on the feelings and the essence of life quality and moral reward, can this feeling occur within the walls of the classroom? It makes me wonder if this cannot be transferred to students, when they have to produce their own item, such as clothing?

Let us take a starting point in that they must sew or re-design a piece of clothing in the arts and design subject. When the students must spend their time, physically and mentally designing a product, creating, making mistakes and mastering, the question is if this will contribute to a feeling of well-being, a reward after the toil? Will mastering sowing a garment promote the feeling of life quality? Mia PorkoHudd, Sinikka Pöllänen and Eila Lindfors (2018) share this point of view as they write that craft is often connected to the concepts of wellbeing and quality of life connected to sustainable crafts. But could this project also contribute to the ownership of their own things, to regain love and the emotional affiliation to things? I wonder if re-design and self-produced clothing can contribute to the garments increased emotional value, that things can have value in virtue of themselves? Hessen specify that empathy, also in the form of sentimentality has a cultural side (2010, p. 137). Something Klepp and Laitala also punctuate in their article (2016). They point out that it appears that the age of clothing is related to frequency of usage and to what extend we like the garment, not to mention the technical durability (the quality, as I interpret it), which does not have the context of price. We take much better care of the things we like. So, will the experience of sowing their own garment, facilitate for an emotional attachment as well as increase its value for the students, which in turn will motivate them to take better care of the garment?

Vitters $\varnothing$ and Strandbakken (2016) believes that we can reduce the number of products if we put more emphasis on quality and longevity. One of the solutions for environmental benefit is to reduce the number of garments we own. Furthermore, they write "It is our assertion that if the effort was aimed at increasing the valuation of clothing and other lasting consumables in terms of better quality and longer durability, it would lead to more knowledge and interest in how the things we surround ourselves with are made" (Vitters $\varnothing$ \& Strandbakken, 2016, p. 19). The way I interpret Vitters $\varnothing$ and Strandbakken, they claim that quality and longer durability in clothing will lead to a greater interest and knowledge of 
how they are made, which in turn contributes to more care and maintenance, with increased lifecycles for the clothes and less consumption as a result. I think we need to turn this around. Whether students get physically aware and master what it is like to create a garment, preferably with conversations around a quality perspective, then I think this will help build up around understanding and knowledge of how clothing is produced, quality and respect for the work that is behind a garment. And this, again, I think can help that they become more conscious of their own consumption. I believe that making a garment, combined with conversations around the quality perspective, will help to build up understanding and knowledge of how clothes are manufactured, quality and respect for the work behind a garment. As Løkvik and Reitan (2017) points out, engaging in a continuous dialogue, the context become clearer and this open up for discussion on the contrast in the mass production of cheap clothes, and "...how rich countries outsource the production to poor countries and consequences this has on us as consumers, environment, economy and health."(2017, p.3). As is evident from Sinikka Pöllänen (2009), art and design subjects are a way to gain an increased understanding of cultural and ecological phenomena, as well as reflect on culture and society, it is about giving the students an individual and balanced relationship between yourself and the world it is part of. Seeing things from others' point of view is important for the ability to reflect and the student's personal growth. And this, again, I think can help to make them more aware of their own consumption and promote for a moral reward, when students can self-realize themselves through clothing without a guilty conscience. This is consistent with the basic values as creativity, identity and human dignity, in General section- values and principles (Kunnskapsdepartementet, 2017).

Orheim and Nielsen (2017) points out that motivation of students is a challenge. On the other hand, real world environmental problems tend to engage students (Løkvik \& Reitan, 2017; Pöllänen, 2009). It is important and motivating for the students to explore and find their own answers to what makes things sustainable (Løkvik \& Reitan, 2017). As I interpret Løkvik and Reitan (2017), it is important to have different approaches to the topic in order to motivate the students and facilitate the students to make their own reflections and engage them to think for themselves. Introducing craft training that supports the full and versatile development of the student's personalities requires understanding of important features of different pedagogies that models and the ability to draw from them in a conscious manner (Pöllänen, 2009).

Foros and Vetlesen points out that there is not much time for reflection in a busy school day $(2015$, p. 251). And it is exactly there I believe the arts and design subject is in a special position. Because when you are in the process designing and creating, and you get into a flow where you can work with the products, and let your mind wonder of. Which allow you to reflect in a subtle way. If you facilitate for a short conversation with students in the beginning of the task, or during the process, it creates both space and time to think. Example of conversations that can be conducted with students: How would you feel if you wash this garment that you have spent a long time making, and the fabric turns out to be of por quality, and that the shape of the garment is ruined? How would you feel if someone throw this garment away after using it twice? The question is if the garment they have invested work and time on, will get the increased value for the students, which in turn provides increased care and maintenance that provide longer lifespan mentioned earlier.

Another challenge is that failed projects that fall into the garbage conflict with the environmental focus. (Orheim and Nielsen, 2017; Pölännen, 2009). Løkvik and Reitan (2017) as well as Pöllänen, (2009) raise basic exercises, training and knowledge before the project as an important basis for avoiding this. I believe that exercises in crafts and proper selected materials will give students the skills to see the connections between what they have learned earlier and can affect the quality of the garment. As Orheim and Nielsen (2017) specify it is important that the garment is of good quality, awareness around material use, knowledge and abilities for implementation are important both in terms of production and assessment of quality, therefore the teachers must transfer this knowledge through demonstration and testing. If you give the students a goal that the garment is to be used by themselves, or given as a gift to someone special, the students take the task more seriously and make something they want, not something they need (Orheim \& Nielsen, 2017). Granted that students summarize the project in the end, and explain words and concepts such as sustainability, the teacher also 
receives feedback on what they have learned during the process (Løkvik \& Reitan, 2017). However, as Orheim and Nielsen (2017) points out, we do not know if the students will actually use their garments and if they don't, some of the expected learning outcome is not achieved.

As Foros and Vetlesen themselves identify, conversations about consumption are important preconditions for the upbringing. Knowledge and an understanding of the world combined with impressions and experiences, can promote the meaning and actualize value choices are important prerequisites for the upbringing. Experience of choices and opinions creates greater hope and vigor in people (Foros \& Vetlesen, 2015). The question is whether such conversations and practical tasks affect how they identify themselves as a consumer in a global community? Will this do something about their consumer perspective, both in terms of relationship to quality, use of materials, time and resources spend use in general. Can this influence their attitudes both to price, quality and their own consumption of mass-produced goods? What experience does the students get through sewing a garment? I think they will get an insight into how demanding it is and how much time it takes as well as a better understanding for the performance of a piece of work. Porko-Hudd, Pöllänen og Lindfors mention that "Craft, design and technology education may help people to see the potentials of sustainable consumption and individual satisfaction of developing one's skills and accomplishing something concrete with one's own hands $(2018$, p.34). This can create a foundation for biophilia, and create a focus on people's working conditions and different environmental impacts that our consumption provides the local environment. The starting point for biophilia is, as I interpret Hessen (2010, p. 147) that we as human beings are more willing to stand up for someone who is closer to us. I think it certainly should be able to stretch to reach living people, and that this can cause upgrowing generations to feel and relate with workers in Bangladesh, which in turn provides a meeting with the basic value in General section-values and principles (Kunnskapsdepartementet, 2017), the value of human dignity.

And as Hessen is writing, you also get life's content through what you do (2010, p. 257). "Impression through adolescence will shape the brain, in which much of the human flexibility lies, but it is also where what makes us creatures of habits, lie" (Hessen, 2010 p. 100). Therefore, it is important to lay a good foundation for environmentally conscious reflections and teaching around our consumption into school life. Here, dialogue and reflections important as Løkvik and Reitan (2017), Foros and Vetlesen (2015) as well as Pöllänen, (2009) underlines. I believe this will promote the students' ability to make ethical considerations such as School of the future (NOU 2015:8) points out that the practical aesthetic subjects are carriers of. I think this will contribute to the combination of practical and theoretical teaching that, according to General section- values and principles (Kunnskapsdepartementet, 2017), facilitates understanding, reflection and critical thinking.

A challenge in the Finnish school Porko-Hudd, Pöllänen og Lindfors (2018) points toward, is lesson hour distribution in craft education to amongst other things influences pedagogical innovation processes, time to develop ideas, design and useful products of good quality. In Norway there is a possibility to do interdisciplinary collaborative projects, thus merging hours with other subjects, but how widespread this is in the Subject of Art and crafts in practice I have not found research on.

Another challenge is that surveys show that a minority of teachers in Norwegian Art and crafts subject have formal qualifications; in addition, fewer number of teachers being educated with formal qualifications now than in previous years, and continuing education in the subject is minimal (Lagerstrøm, Moafi \& Revold, 2014; Espeland, Arnesen, Grønsdal, Holte, Sømoe, Wergwdahl \& Aadlamd, 2011; Perduco Kultur, 2008; Opstad, 2013; Neuberg \& Digranes, 2017). Formal qualifications and continuing education affect teachers' focus on concepts, their repetition, and their attitudes toward the subject (Neuberg \&Digranes, 2017). I think this can create a challenge for the transfer of knowledge through demonstration and testing, as well as conditions for production and assessment of quality, and not least how the teacher facilitates reflection and dialogue.

As I interpret Hessen (2010), does increased consumes equals increased waste, increased CO2 emissions and increased greenhouse gas emissions which threaten our globe. And as previously mentioned, the framework for the conditions change, and that today we are responsible for the emissions that occur in other countries on behalf of our consumption, and thus also a responsibility for the protection of areas and species in a global perspective. We should present to the students how our way of 
living affects the nature, the climate and our society, as General section-values and principles (Kunnskapsdepartementet, 2017) calls for, presented with the knowledge that humans have the opportunity to change habits and identity, because we, as human beings are in an interaction between identity and society, as Hausstätter and Sarromaa (2009), Hessen (2010), Løkvik and Reitan (2017), as well as Pöllänen (2009) specify.

\section{SUMMARY}

What influences our consumption is the culture and society in which we are a part of, as well as the individual's action patterns, that are based on instincts and habits. But we humans have adaptability to change these habits.

Politicians refuse to focus on the individual's responsibility. They can, as we seen, under the direction of their mandate, help to increase the focus on the environment and consumption perspectives in the school trough the white papers. This can provide to bring about a change in attitudes form the bottom up. Social innovation in schools can thus become the key to raising awareness around the topic of consumption. Especially in the subject of Art and crafts, which is in a special position for combining knowledge and an understanding of the world, combined with impressions and experiences. If one assumes that through letting students sew their own garment combined with dialogue around of how the human way of life affects the nature, the climate and our society, one can facilitate for reflection, understanding and empathy in a global perspective, both in terms of human working conditions and an environmental perspective. This can be easier to convey, than a perspective on future generations. But with the climate crisis hanging over our head, it is necessary that we give the students hope for the future. We have to emphasize that there is hope, and that there are choices to be made as well as giving them tools to make them.

These impressions and experiences through sowing a garment can affect attitudes and habits, because students experience a close proximity to the production and will gain new insights and new perspectives. Experiences from sewing a garment will be able to lay a good foundation for environmentally conscious reflections, critical thinking and ethical awareness and can add a basis both when it comes to quality, maintenance and they're own consumption. Sewing a garment is not at least a way to self-realize through clothing without buying clothes. If you make a product, you're proud of, it increases the sentimental value of the garment and can contribute to a heightened desire to care for it. Life should be good to live, and creative processes can contribute to the sense of coping with a difficult situation and facilitate for hope, creativity and identity in a world facing environmental and societal ethical challenges. Therefore, the subject of Art and crafts can form an important basis for a multidisciplinary approach to environmental issues around consumerism.

Suggestion for further research is to undertake such projects in practice, investigations of the implementation in such a sowing project with successive interviews or surveys of teachers and students. 


\section{REFERENCES}

Chalmer, A. (2013). What is this thing called science? (4th Eds.). Open University Press

Carbon Trust. (2011). International Carbon Flows - Clothing. https://prod-drupal-

files.storage.googleapis.com/documents/resource/public/International\%20Carbon\%20Flows\%20\%20Clothing\%20-\%20REPORT.pdf

Espeland M., Arnesen T.E., Grønsdal I.A., Holte A., Sømoe K., Wergedahl H., \& Aadland H. (2013).

Skolefagunders $\varnothing$ kelsen 2011. Praktiske og estetiske fag på barnesteget i norsk grunnskule. [Schoolwork Survey 2011. Practical and aesthetic subjects at primary school in Norway]. (Vol. 2013/7). Høgskulen på Vestlandet. http://hdl.handle.net/11250/152148

Foros, P.B. \& Vetlesen A.J. (2015). Angsten for oppdragelse. Et samfunnsetisk perspektiv på dannelse [The anxiety of the upbringing. A societal ethical perspective on education]. Universitetsforlaget.

Hausstätter, R.S. \& Sanna Sarromaa, S. (2009). Et teoretisk bidrag til en miljørettet pedagogikk [A theoretical contribution to an in-law education]. Norsk pedagogisk tidsskrift, 93(1), 67-75. https://doi.org/10.18261/ISSN1504-2987-2009-01-07

Hessen, D.O. (2010). Natur - Hva skal vi med den? [Nature-What are we going to do with it] (3.utg.). Gyldendal Norsk Forlag.

Kaiser, M \& Ugelvik, I. L. (2000). Hva er vitenskap? [What is Science] (2.utg.). Universitetsforlaget.

Kasa, S. (2016). Bærekraftig forbruk som miljøpolitikk i Norge og Storbritannia: Ulike strategier, felles begrensninger. [Sustainable consumption as environmental policy in Norway and the UK: Different strategies, common constraints.] In G. Vitters $\varnothing$, A. Borch, K. Laitala \& P. Strandbakken (Red.), Forbruk og det grønne skiftet (ss. 39-54). Novus.

Klepp, I.G. \& Laitala, K. (2016). Klærs levetid - LCA på liv og død. [Clothes life-LCA on life and death]. In G. Vitters $\varnothing$, A. Borch, K. Laitala \& P. Strandbakken (Red.), Forbruk og det grønne skiftet (ss. 195-210). Novus.

Kunnskapsdepartementet. (2012). Kunnskap for en felles framtid. Strategiplan [Knowledge for a common future. Strategic plan]. https://www.regjeringen.no/no/dokumenter/kunnskap-for-en-felles-framtid/id696562/

Kunnskapsdepartementet. (2017). Overordnet del-verdier og prinsipper [General section- values and principals]. https://www.regjeringen.no/contentassets/37f2f7e1850046a0a3f676fd45851384/overordnet-del--verdier-og-prinsipper-for-grunnopplaringen.pdf

Lagerstrøm B., Moafi H., and Revold M.K. (2014). Kompetanseprofil I grunnskolen Hovedresultater 2013/2014 [Profile of skills in primary schools Main results 2013/2014]. https://www.ssb.no/utdanning/artikler-ogpublikasjoner/kompetanseprofil-i-grunnskolen

Løkvik C.\& Reitan J.B. (2017). Understanding sustainability through making a basic t-tunic in primary school. In A. Berg, E. Bohemia, L. Buck, T. Gulden, A. Kovacevic \& N. Pavel (Eds.). Building community: Design education for a sustainable future : proceedings of the 19th International Conference on Engineering and Product Design Education, HiOA University, Oslo, Norway, on the 7th \& 8th September 2017. (pp. 158163). The Design Society. https://hdl.handle.net/10642/5666

Meld. St. 22 (2010-2011). Motivasjon - Mestring - Muligheter. Ungdomstrinnet [Motivation - Mastering Possibilities. Lower secondary education]. https://www.regjeringen.no/globalassets/upload/kd/vedlegg/taler-ogpresentasjoner/ungdomstrinnsmelding_pressekonferanse.pdf

Meld. St. 28 (2015-2016). Fag - Fordypning - Forståelse - En fornyelse av Kunnskapsløftet [Subjectsspecialization- understanding: a renewal of the Knowledge Promotion]. https://www.regjeringen.no/no/dokumenter/meld.-st.-28-20152016/id2483955/

Neuberg, A. \& Digranes I. (2017). Common language for community building. In A. Berg, E. Bohemia, L. Buck, T. Gulden, A. Kovacevic, N. Pavel (Eds.), Building community: Design education for a sustainable future : proceedings of the 19th International Conference on Engineering and Product Design Education, HiOA University, Oslo, Norway, on the 7th \& 8th September 2017 (pp. 394-399). The Design Society. https://hdl.handle.net/10642/6337 
NOU 2015:8. (2015). Fremtidens skole. Fornyelse av fag og kompetanser [Future school. Renewal of subjects and competencies]. https://nettsteder.regjeringen.no/fremtidensskole/nou-2015-8/

Opstad K.D. (2013). Vi trenger ikke kunst og håndverk for å bli lærere, [We do not need Art and crafts to become teachers]. FORM, (5), 22-23. http://media.wix.com/ugd/75f35c_5c71e23e1b06430da40987e64715a061.pdf

Orheim, M.S. \& Nielsen, L.M. (2017) Redesign of Garments in General Education: A Path to Reduced Consumption. In A. Berg, E. Bohemia, L. Buck, T. Gulden, A. Kovacevic \& N. Pavel (Eds.), DS 88: Proceedings of the 19th International Conference on Engineering and Product Design Education (E\&PDE17), Building Community: Design Education for a Sustainable Future, Oslo, Norway, 7 \& 8 September 2017 (pp. 405-410). Design Society. https://hdl.handle.net/10642/6227

Patel, R \& Davidson, B. (1999). Forskningsmetodikkens grunnlag [The basis of the research methodology] (2.utg.). Universitetsforlaget.

Perduco Kultur, (2008). Skolelederundersøkelsen [Headmaster survey]. https://slideplayer.no/slide/2159119/

Pöllänen, S. (2009). Contextualising Craft: Pedagogical Models for Craft Education. International Journal of Art and Design Education, 28(3), 249-206. https://doi.org/10.1111/j.1476-8070.2009.01619.x

Porko-Hudd M., Pöllänen S. \& Lindfors E. (2018). Common and holistic crafts education in Finland. Techne Serien A, 25(3), 26-38. https://journals.oslomet.no/index.php/techneA/article/view/3025

SSB (1999). Forbrukerundersøkelsen, 1998. [Consumer survey]. https://www.ssb.no/inntekt-ogforbruk/statistikker/fbu/aar/1999-12-13

SSB. (2013). Statistikkbanken [Statbank]. https://www.ssb.no/statistikkbanken/SelectVarVal/Define.asp?subjectcode=al\&Productld=al\&MainTable $=$ UtgHusVare\&SubTable=1\&PLanguage=0\&nvl=True\&Qid=0\&gruppe1=Hele\&gruppe2=Hele\&VS1=Forbr ukHushold2\&VS2=\&mt=0\&KortNavnWeb=fbu\&CMSSubjectArea=\&StatVariant $=\&$ checked $=$ true

Strand, P. (2014). Vi kjøper mer av det meste [We buy more of the most]. SSB. https://www.ssb.no/inntekt-ogforbruk/artikler-og-publikasjoner/vi-kjoper-mer-av-det-meste

Strandbakken, P. (2016). Produktlevetid og produktkvalitet som redusert forbruk? [Product life and product quality that reduced consumption?]. In G. Vitters $\varnothing$, A. Borch, K. Laitala \& P. Strandbakken (Red.), Forbruk og det grønne skiftet (ss. 185-194). Novus.

Vitters $\varnothing$, G. \& Strandbakken, P. (2016). Forbruk og det grønne skiftet. [Consumption and the green shift]. In G.Vitters $\varnothing$, A. Borch, K. Laitala \& P. Strandbakken (Red.), Forbruk og det grønne skiftet (ss. 9-24). Novus.

\footnotetext{
${ }^{1}$ First published as Neuberg, A. (2019). Social innovation for modified consumption by means of the school subject Art and craft. Conference Proceedings of the Academy for Design Innovation Management, 2(1). The article is republished with permission.
} 